engineering industries as a whole, as well as for engineering standards. On these, it would deal direct with the British Standards Institution, but it would not deal with the Institution's work on consumer protection. It would also take over from the Board of Trade the responsibility for determining standard weights and measures. The central co-ordination of measures to promote the growth of industrial productivity, through the National Economic Development Committees and by other means, was a primary concern of the First Secretary of State and Secretary of State for Economic Affairs, but departmental Ministers carried direct responsibility for encouraging productivity in those industries which their departments sponsored. The Minister of Technology would, accordingly, have this responsibility for the mechanical and electrical engineering industries. The Board of Trade would continue to deal direct with these industries on exports, commercial relations and on its other functions and responsibilities which affect industry as a whole.

\section{Scottish Hydroelectric Schemes}

IN a statement to the House of Commons on November 29, the Secretary of State for Scotland, Mr. W. Ross, said that he had completed his study of the report into the Enquiry into the Fado-Fionn and Laidon hydroelectric schemes. The report concluded that neither scheme was needed, at least up to 1975 , because adequate capacity would be provided by large new stations which must be commissioned by that time elsewhere in Scotland. These would provide power at a lower cost than either of the projected schemes. The assumptions on which these schemes were assessed are subject to change with economic circumstances. Other factors affecting the pattern of electricity generation might also arise out of the continuing development of methods of generation and the fuller exploitation of pumped storage. While, in the light of the report, Mr. Ross was not prepared to confirm the schemes now, he did not regard this as precluding their reconsideration in the future, and when more information was available about future generation plans the North of Scotland Hydro-Electric Board would be free to submit them again.

\section{Colour Television}

IN a written reply in the House of Commons on December 1, the Postmaster General, Mr. W. Benn, stated that the Television Advisory Committee had recommended to him that colour television be introduced on 625 lines only, using the PAL system of transmission, and that he was now considering this advice.

\section{British Government Aid Overseas}

IN reply to questions in the House of Commons on November 30, the Minister of Overseas Development, Mrs. B. Castle, said that we had now reached the second year of the arrangement under which the British Government contributed $£ 250,000$ a year for three years to the recurrent costs of University College, Salisbury. Since the College provides higher education for students of all races in Rhodesia, and operates under Royal Charter, the Government had decided to continue its assistance to the College so long as it is satisfied that conditions continue to exist under which the College is able to discharge this function. If it became clear to the Government that the multi-racial function of the University was being undermined, the Government would reconsider the allocation of aid. British Government contributions in 1964-65 of $£ 6.5$ million to the International Bank for Reconstruction and Development, $£ 5.1$ million to the International Finance Corporation, $£ 45$ million to the International Development Association, $\mathbf{2 2 . 7}$ million to the United Nations Expanded Programme of Technical Assistance and Special Fund, $£ 31.3$ million to the United Nations Relief and Works Agency, £3.1 million to the United
Nations Children's Fund, $£ 10.1$ million to the United Nations Korean Reconstruction Agency, $£ 1.5$ million to United Nations Assistance to the Congo, $£ 1.2$ million to the World Food Programme and $\$ 11$ million to the Indus Basin Development Scheme, brought the total contributions to multilateral agencies since $1946-47$ to $£ 137 \cdot 5$ million. Official aid and private investment in developing countries amounted to $1 \cdot 1$ per cent of Britain's gross national product in $\mathbf{1 9 6 4}$.

\section{The Bodleian Library}

THE annual report of the Curators of the Bodleian Library for the year ended July 31, 1964, notes an overall increase of 10,000 on the previous year's figures for issues of books and manuscripts to readers and staff, while an increase in the number of newly admitted readers was almost wholly in those who were not members of the University. The ratio betweon members and non-members, for long steady at $3: 1$, is now almost $5: 2$ (University of Oxford. Pp. 28. Supplement No. 9 to the University Gazette, August 1965. Oxford: The University, 1965. 2s. 6d.). Besides lists of publications by members of the staff during the year, the report refers to the work of the Department of Western Manuscripts and to that of the Department of Printed Books, where accessions totalled 56,244 volumes and 110,330 parts, compared with 44,826 and 121,276, respectively, in 1962-63; 293,909 microfilm exposures, 16,460 photostats and 712 bromide prints were made from library material and from manuscripts deposited for the purpose.

\section{Lord Nuffield's Benefactions for the Advance of Medicine}

THE Report for 1963-64 of Lord Nuffield's Benefactions for the Advance of Medicine (University of Oxford. Pp. 28. Oxford: The University, 1965) includes lists of staff and publications by the Department of Clinical Medicine, the research interests of which are in gastroenterology, haematology and population pathology. Other Departments, the publications of which are listed, include Surgery, Obstetrics and Gynaecology; Anaesthetics; Orthopaedic Surgery, Pathology, Clinical Biochemistry, and the Nuffield Institute for Medical Research. Research projects in these departments are also briefly listed.

\section{Solis and Foundations}

An important application of soil research concerns the behaviour of soil particles under the influence of loading, and a recent publication, entitled Soils and Foundations: 1 (Building Research Station Digest (Second Series), No. 63. Pp. 6. London: H.M.S.O., 1965. 4d.), deals with the numerous factors that interact with each other and must be kept in mind in building-design. The movement of water in the soil is determined by its texture and by the pressure exerted by a foundation load. Shrinkage and swelling may operate simultaneously, as when structural load is equal to weight removed in excavation. Settlement of the load is rapid on sands but may continue for many years on clays. The differences in settlement between strips, rafts and piles are discussed. Attention is also directed to shrinkage and swelling brought about by rainfall and vegetation and removal of trees on a building site, and the tendency for outside walls to move and produce cracks. Other matters dealt with include peat soils, made-up ground, frost heave and 'quick-sand' conditions.

\section{Timber as Building Material in Hot Climates}

THE behaviour of timber used as a building material, under what may be called 'aggressive' environmental conditions, has long been a matter of discussion and practical importance; it is a subject of almost endless research. In Africa the effects of climatic extremes on 